\title{
Histone deacetylase inhibitors strongly sensitise neuroblastoma cells to TRAIL-induced apoptosis by a caspases-dependent increase of the pro- to anti-apoptotic proteins ratio
}

\author{
Annick Mühlethaler-Mottet ${ }^{1}$, Marjorie Flahaut ${ }^{1}$, Katia Balmas Bourloud ${ }^{1}$, \\ Katya Auderset ${ }^{1}$, Roland Meier ${ }^{1}$, Jean-Marc Joseph ${ }^{2}$ and Nicole Gross*1
}

Address: ${ }^{P}$ Paediatric Oncology Research, Paediatric Department, University Hospital CHUV, CH-1011 Lausanne, Switzerland and ${ }^{2}$ Paediatric Surgery, Paediatric Department, University Hospital CHUV, CH-1011 Lausanne, Switzerland

Email: Annick Mühlethaler-Mottet - Annick.Muhlethaler@chuv.ch; Marjorie Flahaut - Marjorie.Flahaut@chuv.ch; Katia Balmas Bourloud - Katia.Balmas-Bourloud@chuv.ch; Katya Auderset - Katya.Auderset@chuv.ch; Roland Meier - Roland.Meier@chuv.ch; Jean-Marc Joseph - Jean-Marc.Joseph@chuv.ch; Nicole Gross* - Nicole.Gross@chuv.ch

* Corresponding author

Published: 24 August 2006

BMC Cancer 2006, 6:214 doi:|0.1 |86/|47|-2407-6-2|4
Received: 15 June 2006

Accepted: 24 August 2006

This article is available from: http://www.biomedcentral.com/I47I-2407/6/2I4

(C) 2006 Mühlethaler-Mottet et al; licensee BioMed Central Ltd.

This is an Open Access article distributed under the terms of the Creative Commons Attribution License (http://creativecommons.org/licenses/by/2.0), which permits unrestricted use, distribution, and reproduction in any medium, provided the original work is properly cited.

\begin{abstract}
Background: Neuroblastoma (NB) is the second most common solid childhood tumour, an aggressive disease for which new therapeutic strategies are strongly needed. Tumour necrosis factor-related apoptosis-inducing ligand (TRAIL) selectively induces apoptosis in most tumour cells, but not in normal tissues and therefore represents a valuable candidate in apoptosis-inducing therapies. Caspase- 8 is silenced in a subset of highly malignant NB cells, which results in full TRAIL resistance. In addition, despite constitutive caspase-8 expression, or its possible restoration by different strategies, NB cells remain weakly sensitive to TRAIL indicating a need to develop strategies to sensitise NB cells to TRAIL. Histone deacetylase inhibitors (HDACls) are a new class of anti-cancer agent inducing apoptosis or cell cycle arrest in tumour cells with very low toxicity toward normal cells. Although HDACls were recently shown to increase death induced by TRAIL in weakly TRAIL-sensitive tumour cells, the precise involved sensitisation mechanisms have not been fully identified.
\end{abstract}

Methods: NB cell lines were treated with various doses of HDACls and TRAIL, then cytotoxicity was analysed by MTS/PMS proliferation assays, apoptosis was measured by the Propidium staining method, caspases activity by colorimetric protease assays, and (in)activation of apoptotic proteins by immunoblotting.

Results: Sub-toxic doses of HDACls strongly sensitised caspase-8 positive NB cell lines to TRAIL induced apoptosis in a caspases dependent manner. Combined treatments increased the activation of caspases and Bid, and the inactivation of the anti-apoptotic proteins XIAP, Bcl-x, RIP, and survivin, thereby increasing the pro- to anti-apoptotic protein ratio. It also enhanced the activation of the mitochondrial pathway. Interestingly, the kinetics of caspases activation and inactivation of anti-apoptotic proteins is accelerated by combined treatment with TRAIL and HDACls compared to TRAIL alone. In contrast, cell surface expression of TRAIL-receptors or TRAIL is not affected by sub-toxic doses of HDACls.

Conclusion: HDACls were shown to activate the mitochondrial pathway and to sensitise NB cells to TRAIL by enhancing the amplitude of the apoptotic cascade and by restoring an apoptosis-prone ratio of pro- to antiapoptotic proteins. Combining HDACls and TRAIL could therefore represent a weakly toxic and promising strategy to target TRAIL-resistant tumours such as neuroblastomas. 


\section{Background}

Neuroblastoma (NB) is the most frequent solid extracranial tumour in children and is a major cause of death from neoplasia in infancy [1]. These tumours are clinically and biologically heterogeneous, with cell populations differing in their genetic programs, maturation stage and malignant potential [2]. Clinically, spontaneous regressions and tumour maturation are frequent in infants or in low stage tumours, whereas older children often present at diagnosis with high stage progressive and metastatic disease and their overall prognosis is poor [2]. Little improvement in therapeutic options has been made in the last decade, requiring a urgent need for the development of new therapies.

Anti-cancer therapies mediate their cytotoxic effect by predominantly inducing apoptosis in tumour cells. Apoptosis may be induced by triggering the death receptors (extrinsic pathway) or the mitochondria (intrinsic pathway) leading to the activation of effector caspases [3]. Tumour necrosis factor-related apoptosis-inducing ligand (TRAIL) is a promising candidate for therapy of many forms of cancer as it selectively induces cell death in transformed cells, sparing normal tissues [4]. TRAIL mediates apoptosis by activation of the death receptor pathway. Its interaction with TRAIL-R1 and -R2 receptors leads to recruitment of adaptor FADD and initiator caspase- 8 to the DISC, resulting in caspase- 8 activation and initiation of a cell death cascade by direct cleavage of effector caspases $[4,5]$. The process is positively regulated and amplified by caspase-3-mediated activation of caspase-8 [6,7], and/or by parallel activation of the mitochondrial pathway via caspase-8-dependent cleavage of Bid [8], resulting in activation of the apoptosome through Bax and Bak oligomerisation and the release of cytochrome-c and Smac/ DIABLO into the cytosol. Conversely, negative regulation is promoted by the caspase- 8 antagonist c-FLIP [9] or by anti-apoptotic $\mathrm{Bcl}-2$ and $\mathrm{Bcl}-\mathrm{x}_{\mathrm{L}}$ mediated blockade of mitochondria activation [10]. In addition, other inhibitors of apoptosis proteins (IAPs), such as cIAP-1/-2 and XIAP [11] interact with effector caspases, which are neutralized by Smac/DIABLO [3]. Survivin, an other IAP shown to be over-expressed in most tumours, protects cancer cells from apoptosis by interacting with Smac/DIABLO.

Resistance to TRAIL-induced apoptosis in various tumours was described to be caused by the deregulation of diverse signalling molecules such as down-regulation of TRAIL-receptors, caspase- 8 , caspase-10 or Bax, or overexpression of $\mathrm{c}-\mathrm{FLIP}, \mathrm{Bcl}-2, \mathrm{Bcl}-\mathrm{x}_{\mathrm{L}}$ or survivin [12]. In $\mathrm{N}-$ type NB cells, resistance to TRAIL was attributed to the down-regulation of caspase- 8 expression by hypermethylation or allelic deletion [13-15], as well as to the downregulation of cell surface TRAIL-R1/-R2 expression [16].
Numerous TRAIL resistant tumour cell lines were reported to be sensitised to TRAIL by combined treatments with chemotherapeutic agents, cycloheximide (CHX), IFN- $\gamma$ or irradiation by diverse cell-type specific mechanisms $[17,18]$. We have previously shown that NB cells could be sensitised to TRAIL by subtoxic doses of chemotherapeutic drugs or CHX by the activation of extrinsic and intrinsic apoptotic pathways and caspases-dependent cleavage of XIAP, Bcl- $\mathrm{x}_{\mathrm{L}}$ and RIP [19]. However as chemotherapeutic drugs are non-specifically and highly toxic toward nontumoral cells, it may be beneficial to develop alternative and less toxic therapeutic strategies that synergise with TRAIL.

Histone deacetylase inhibitors (HDACIs) are a new class of promising anti-cancer agents which inhibit tumour growth both in vitro and in vivo with very low toxicity toward normal cells [20]. Recently, several HDAC inhibitors have entered Phase I and Phase II clinical trials and demonstrate encouraging anti-tumour activity in a variety of cancer types [21]. The anti-tumour effect of HDACIs was proposed to result from accumulation of acetylated histones leading to activation of genes involved in inhibition of tumour cell growth [20]. Altered activities of histone deacetylases or histone acetyl transferases are indeed involved in different human cancer [22,23]. HDACIs mechanism of action appears to involve cell cycle arrest, induction of apoptosis and differentiation both in vitro and in vivo [21,22]. The mechanisms of induction of apoptosis by HDACIs are cell type specific and involve the activation of the intrinsic apoptotic pathways. HDACIs can also synergise with TRAIL to induce apoptosis by various mechanisms depending on tumour types, such as increased expression of TRAIL-receptors and TRAIL [24$28]$, decrease in c-FLIP $[24,26,29], \mathrm{Bcl}_{\mathrm{L}}[30]$, XIAP and Bcl-2 expression (or activation) [31], or increased formation of the DISC [26,32].

This is the first report describing the detailed mechanisms of TRAIL sensitization by HDACIs in neuroblastoma cells. The analysis of the mechanisms by which the three HDACIs, sodium butyrate (NaB), Trichostatin A (TSA) and suberoylanilide hydroxamic acid (SAHA) enhance the action of TRAIL, demonstrates that HDACIs enhance caspases activation and restores a positive ratio between proand anti-apoptotic proteins in favour of apoptosis. In addition, we demonstrate that HDACIs also potentiate TRAIL action by increasing the amplitude and the kinetics of the apoptotic process. The association of TRAIL and HDACIs, two non-toxic anti-cancer agents, could be of therapeutic benefit for the treatment of children with NB. 


\section{Methods \\ Cell culture and reagents}

The caspases- 8 positive neuroblastoma cells SH-EP, SHEP FADD-DN [33], SH-EP-FLIP [34] and SK-N-AS were grown in DMEM medium supplemented with $10 \%$ of FCS, $200 \mu \mathrm{g} / \mathrm{ml}$ gentamicin (Essex Chemie AG). Cells were incubated with indicated amount of soluble recombinant TRAIL (a gift from J. Tschopp) and cross-linking mouse anti-Flag Ab M2 (Sigma) with a constant ratio of 1/ 5 of TRAIL to M2 respectively. Sodium butyrate (Fluka) was dissolved in $\mathrm{H}_{2} \mathrm{O}$ and stored at $-20^{\circ} \mathrm{C}$. SAHA (Biovision) and TSA (Sigma) were dissolved in DMSO and store at $-20^{\circ} \mathrm{C}$. Cells were pretreated $30 \mathrm{~min}$ with caspases inhibitors zVAD-fmk (100 $\mu \mathrm{M}$, Bachem), zVDVAD-fmk (50 $\mu \mathrm{M}$, Calbiochem), zIETD-fmk, zDEVD-fmk, and zLEHD-fmk ( $50 \mu \mathrm{M}, \mathrm{R} \& \mathrm{D}$ systems) before TRAIL or HDACIs treatments.

\section{Cell viability assays}

Cells $\left(1-2.5^{*} 10^{5} /\right.$ well in 96-well-plates; $\left.100 \mu \mathrm{l}\right)$ were plated $24 \mathrm{~h}$ before treatment and incubated with TRAIL and/or HDACIs for $48 \mathrm{~h}$. Assays were performed in quadruplicates. Viability was measured using the MTS/PMS cell proliferation kit from Promega according to manufacturer's instructions. Percentage of cell viability as compared to untreated controls was calculated.

\section{Measurement of apoptosis by detection of sub-diploid population}

Cells were harvested by trypsinization, washed twice with ice-cold PBS, resuspended in $1 \mathrm{ml}$ of ice-cold PBS, and fixed with $3 \mathrm{ml}$ of $100 \%$ ice-cold ethanol for $1 \mathrm{~h}$ at $4{ }^{\circ} \mathrm{C}$. For staining with propidium iodide (PI), cells were washed twice in ice-cold PBS and incubated for at least 30 min at room temperature in $0.2 \mathrm{ml}$ of PBS containing 200 $\mu \mathrm{g} / \mathrm{ml}$ RNase A and $10 \mu \mathrm{g} / \mathrm{ml}$ propidium iodide. The stained cells were analyzed using a FACScan flow cytometer (Becton Dickinson).

\section{Immunoblotting}

Whole cell extracts were prepared as already described [14]. Protein extracts $(30-50 \mu \mathrm{g})$ were loaded on $12 \%$ SDS-PAGE and transferred on nitrocellulose membranes. Blots were saturated with 5\% skim milk, $0.1 \%$ Tween 20 in TBS and revealed using mouse monoclonal antibodies to detect caspase-8 (MBL), caspase-2 (Apotech corporation), caspase-3, caspase-7, XIAP, RIP, cytochrome-c (BD Pharmingen), AIF (Santa Cruz), $\beta$-actin (Sigma). Polyclonal rabbit antibodies were used to detect caspase-9 (Cell Signaling), Bid, Bcl- $\mathrm{x}_{\mathrm{L}}$ (BD Transduction Laboratories), Bim (Imgenex), survivin ( $R \& D$ systems). Binding of the first antibody was revealed by incubation with either goat anti-mouse IgG (Jackson ImmunoResearch) or goat antirabbit IgG (Nordic Immunological Laboratories). Bound antibodies were detected using the Lumi-light western blotting substrate (Roche) according manufacturer's instructions.

\section{Caspases activities}

Caspases-8, -2, -3 and -9 protease activities were measured using the caspases-3, $-8,-9$ colorimetric protease assay kits from MBL and caspases- 2 colorimetric substrate VDVADpNA from Alexis. Cytosolic lysates were prepared after TRAIL and/or HDACIs treatments according to manufacturer instructions. One hundred $\mu \mathrm{g}$ of protein extracts were incubated with $200 \mu \mathrm{M}$ of IETD-pNA, VDVAD-pNA, DEVD-pNA, and LEHD-pNA colorimetric substrates for 3 $\mathrm{h}$ at $37^{\circ} \mathrm{C}$. Cell lysates were incubated with $10 \mu \mathrm{M}$ of caspase inhibitor (zIETD-fmk, zVDVAD-fmk, zDEVD-fmk, or zLEHD-fmk) for $30 \mathrm{~min}$ before addition of the respective caspase substrate for control experiments. Hydrolysed pNA was detected using a microtiter plate reader at 405 nm. Background absorbance from cell lysates and buffers were subtracted from the absorbance of stimulated and unstimulated samples before calculation of relative caspases activities.

\section{Analysis of mitochondrial transmembrane potential}

The drop of mitochondrial membrane potential $\Delta \Psi \mathrm{m}$ was measured by staining the cells with the fluorescent dye JC1 [35] according to manufacturer's protocol (Calbiochem). Loss of $\Delta \Psi \mathrm{m}$ resulting in reduction of red aggregates was measured by flow cytometry using the FL2 channel (550-650 nm) (FACScan, Becton Dickinson). Results are given in percentage of cells with low $\Delta \Psi \mathrm{m}$ compared to untreated controls.

\section{Cell surface immunostaining}

Cells were washed in FACS buffer (RPMI, 10 \% FCS, 2 mM EDTA) and stained with mouse monoclonal antibodies anti-TRAIL-R1, -TRAIl-R2 and -TRAIL (Alexis), followed by goat secondary antibody conjugated with FITC (Caltag laboratory) and analysed by FACScan (Beckton Dinkinson).

\section{Transfection with siRNAs}

Survivin siRNA targets nucleotides 235-253 of survivin mRNA 5'-AAGGAGCTGGAAGGCTGGGAGTT-3' and control siRNA is composed of the inverse sequence $5^{\prime}$ AAGAGGGTCGGAAGGTCGAGG-3', as described previously [36]. siRNAs were a gift from the lab of Uwe Zangemeister-Wittke. 180'000 cells/well were plated in 12 wells $(1 \mathrm{ml})$ and transfected $8 \mathrm{~h}$ later with $100 \mathrm{nM}$ or $25 \mathrm{nM}$ of siRNAs with $3 \mu \mathrm{l}$ or $2 \mu \mathrm{l}$ respectively of Lipofectamine 2000 according to manufacturer's instructions (Invitrogen). Sixteen h after transfection, cells were plated in 96 wells (10'000 cells/well) and induced $24 \mathrm{~h}$ later with TRAIL and/or HDACIs for $48 \mathrm{~h}$. 

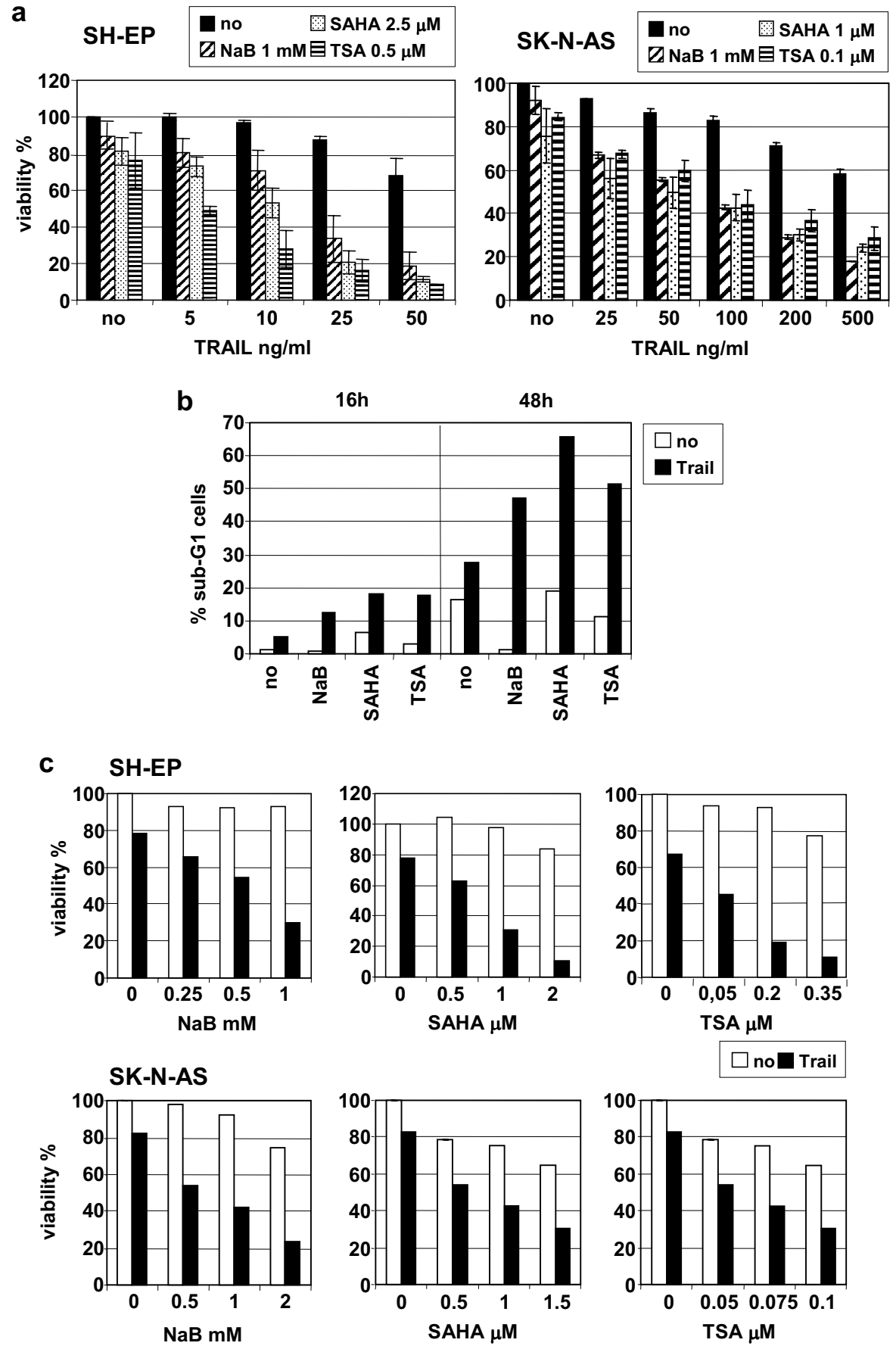

Figure I

Subtoxic doses of NaB, SAHA and TSA sensitise NB cells to TRAIL-induced cell death. A Sensitisation is dependent on the concentration of TRAIL. SH-EP and SK-N-AS cells were treated with the indicated amount of TRAIL and NaB, SAHA or TSA for $48 \mathrm{~h}$. Cell death was measured by MTS/PMS cell proliferation assays. Mean values of three or two independent experiments are shown for SH-EP or SK-N-AS cells, respectively. B Subtoxic doses of NaB, SAHA and TSA sensitise NB cells to TRAIL-induced cell death. Sub-GI apoptotic cells were detected by the propidium staining method after stimulation for $16 \mathrm{~h}$ or $48 \mathrm{~h}$ with I mM of NaB, $2.5 \mu \mathrm{M}$ of SAHA or $0.5 \mu \mathrm{M}$ of TSA in absence or in presence of TRAIL ( $25 \mathrm{ng} / \mathrm{ml})$ and M2 (I25 $\mathrm{ng} / \mathrm{ml})$. C Subtoxic doses of NaB, SAHA and TSA sensitise NB cells to TRAlL-induced cell death. Sensitisation is dependent on the concentration of HDACls. SH-EP cells were treated with TRAIL $50 \mathrm{ng} / \mathrm{ml}$ and $M 2(250 \mathrm{ng} / \mathrm{ml})$ and SK-N-AS cells with TRAIL $100 \mathrm{ng} / \mathrm{ml}$ and $\mathrm{M} 2(500 \mathrm{ng} / \mathrm{ml})$, and indicated amount of NaB, SAHA or TSA for $48 \mathrm{~h}$. 
a
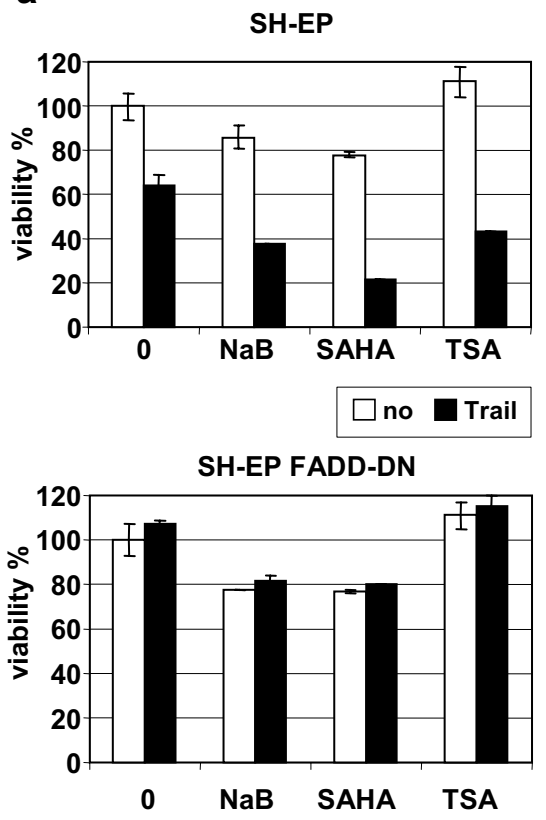

b
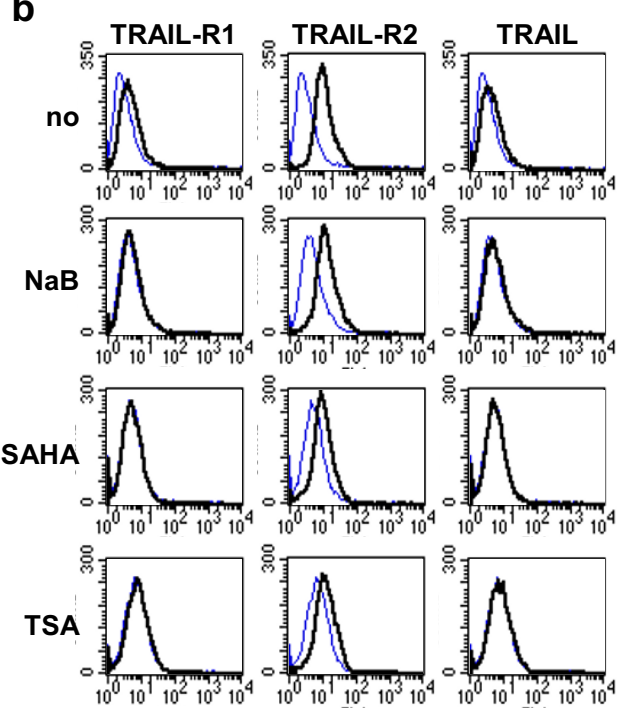

Figure 2

Sensitisation by HDACls to TRAIL requires an intact TRAIL receptor pathway. A SH-EP and SH-EP-FADDDN cells were treated $48 \mathrm{~h}$ without TRAIL or with TRAIL $(50 \mathrm{ng} / \mathrm{ml})$ and $\mathrm{M} 2(250 \mathrm{ng} / \mathrm{ml})$ in the presence or absence of $\mathrm{NaB}(\mathrm{I} \mathrm{mM})$, SAHA $(2.5 \mu \mathrm{M})$ or TSA $(0.5 \mu \mathrm{M})$. B No induction in cell surface expression of TRAIL and TRAIL receptors induced by HDACls in NB cells. SH-EP cells treated for $24 \mathrm{~h}$ with $\mathrm{NaB}(\mathrm{I} \mathrm{mM})$, SAHA $(2.5 \mu \mathrm{M})$ or TSA $(0.5 \mu \mathrm{M})$ were incubated with antibody against TRAIL-RI, TRAIL-R2 and TRAIL (thick line) or without primary antibody (thin line) and then with a FITC labelled secondary antibody.

\section{Results \\ HDACls strongly sensitise caspases-8 positive NB cell lines to TRAIL-induced apoptosis}

We have previously shown that caspases- 8 positive NB cells are weakly sensitive to TRAIL and could be sensitised by subtoxic concentrations of chemotherapeutic drugs such as doxorubicin or cisplatin [19]. Here we analysed the ability of three different HDACIs belonging to two structural classes, the short-chain fatty acid $\mathrm{NaB}$ and the hydroxamic acids SAHA and TSA to sensitise these NB cells to TRAIL-mediated apoptosis. Treatments with subtoxic concentrations of NaB, SAHA and TSA highly increased TRAIL-induced apoptosis in SH-EP cell line as analysed by proliferation assays (Fig. 1a) or by the propidium iodide staining method (Fig. 1b). SK-N-AS cells, which are more resistant to TRAIL-induced apoptosis, could also be strongly sensitised to TRAIL by HDACIs (Fig. 1a). Potentiation of cell death by co-treatment with TRAIL and HDACIs was dependent on both the concentration of TRAIL and HDACIs (Fig. 1a and 1c).

In contrast, HDACIs could not sensitise NB cells to low doses of classical chemotherapeutic drugs, such as Doxorubicin, Taxol, Cisplatin or Etoposide, except for a very weak sensitisation observed when DOX was combined with TSA (data not shown). In addition, HDACIs could not overcome the resistance of caspases- 8 positive NB cells to Fas ligand (data not shown), which could in contrast be sensitised by shRNAs-mediated downregulation of c-FLIP ${ }_{L}[34]$.

\section{Sensitisation to TRAIL by HDACls requires the integrity of the receptor pathway, without involving TRAIL-receptors expression}

The contribution of the death receptor pathway in this sensitisation mechanism was analysed using SH-EP cells over-expressing a FADD dominant-negative protein (FADD-DN), lacking the death effector domain required for caspase-8 recruitment to the DISC [33]. SH-EP-FADDDN were completely resistant to TRAIL and could not be re-sensitised to TRAIL by co-treatment with subtoxic doses of NaB, SAHA or TSA (Fig. 2a). In addition, SH-EP cells over-expressing c-FLIP ${ }_{\mathrm{L}}$ and caspase-8/-10 negative $\mathrm{N}$ type NB cells could not be sensitised to TRAIL by combined treatments with TRAIL and HDACIs (data not shown). These findings indicate that the integrity of the TRAIL-receptor pathway is necessary for TRAIL sensitisation by $\mathrm{NaB}$, SAHA and TSA.

To analyse the detailed mechanisms by which these HDACIs enhance the action of TRAIL, the cell surface expression of TRAIL and the TRAIL-receptors was measured by FACS. Indeed, recent studies have described that HDACIs induced the expression of TRAIL and TRAIL-receptors in leukaemia cells, breast and colon cancer cells [24-28], 
a

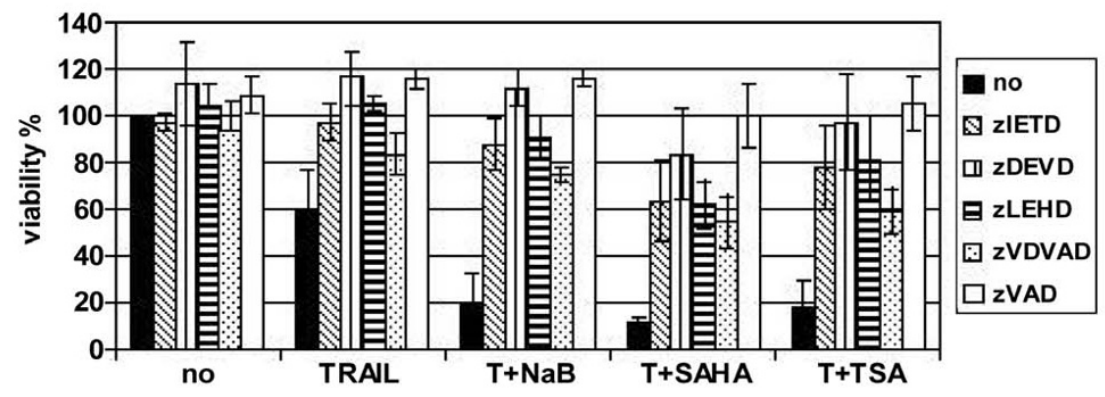

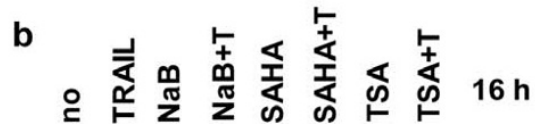
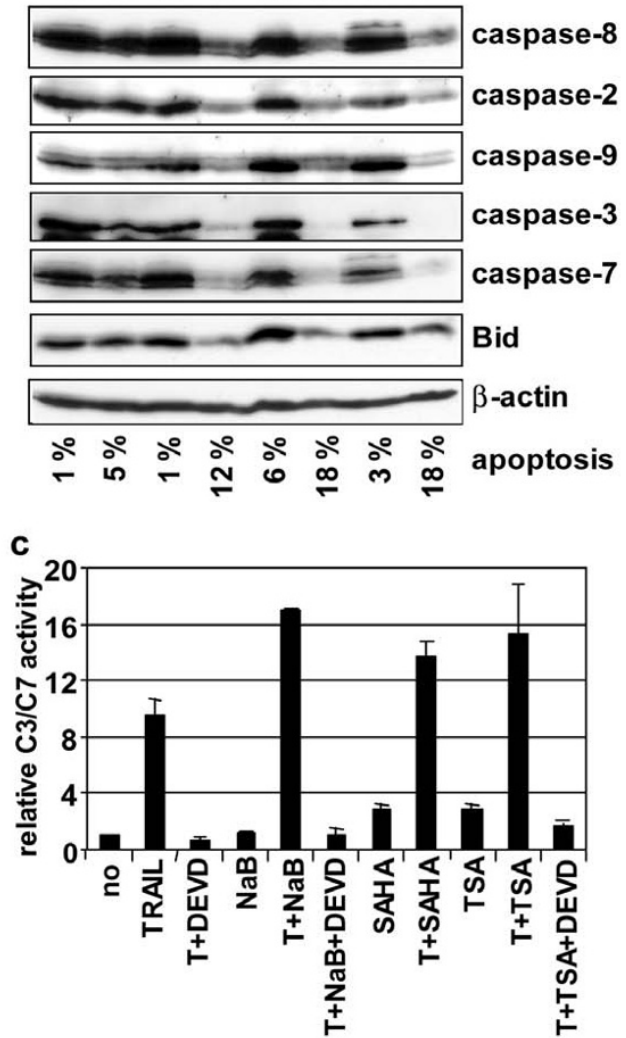

Figure 3

HDACIs and TRAIL induce caspases-dependent apoptosis. A SH-EP cells were uninduced (no) or induced for $48 \mathrm{~h}$ by TRAIL $(25 \mathrm{ng} / \mathrm{ml})$ and M2 (I $25 \mathrm{ng} / \mathrm{ml})(\mathrm{T})$ and NaB (I mM), SAHA $(2.5 \mu \mathrm{M})$ or TSA $(0.5 \mu \mathrm{M})$, without caspases inhibitors, or with zIETD-fmk, zDEVD-fmk, zLEHD-fmk, zVDVAD-fmk or zVAD-fmk. Mean values of three representative experiments are shown. B Caspases cleavage is increased by simultaneous treatments with TRAIL and HDACls. SH-EP cells were untreated (no) or treated with TRAIL $(25 \mathrm{ng} / \mathrm{ml})$ and M2 (I25 ng/ml) (T) and/or NaB (I mM), SAHA (2.5 $\mu$ M) or TSA (0.5 $\mu$ M) for I6 h. Whole cell extracts were analysed by immunoblotting for the cleavage of caspases-8, $-2,-9,-3$ and -7 , and Bid. $\beta$-actin was used as loading control. Percentage of apoptotic cells (sub-GI population) as analysed by the PI staining method after I6 $\mathrm{h}$ of treatments are indicated. C Caspase-3-like activities were induced by TRAIL/HDACls co-treatments. Hydrolysis of DEVD-pNA was measured in SH-EP cells unstimulated (no) or treated with TRAIL (T) and/or NaB, SAHA or TSA for $16 \mathrm{~h}$ as in Fig. $3 \mathrm{~b}$. The caspase-3-like activities of stimulated cells, relative to unstimulated cells are indicated. The caspase-3/-7 inhibitor DEVD-fmk was used as control to inhibit hydrolysis of DEVD-pNA. 

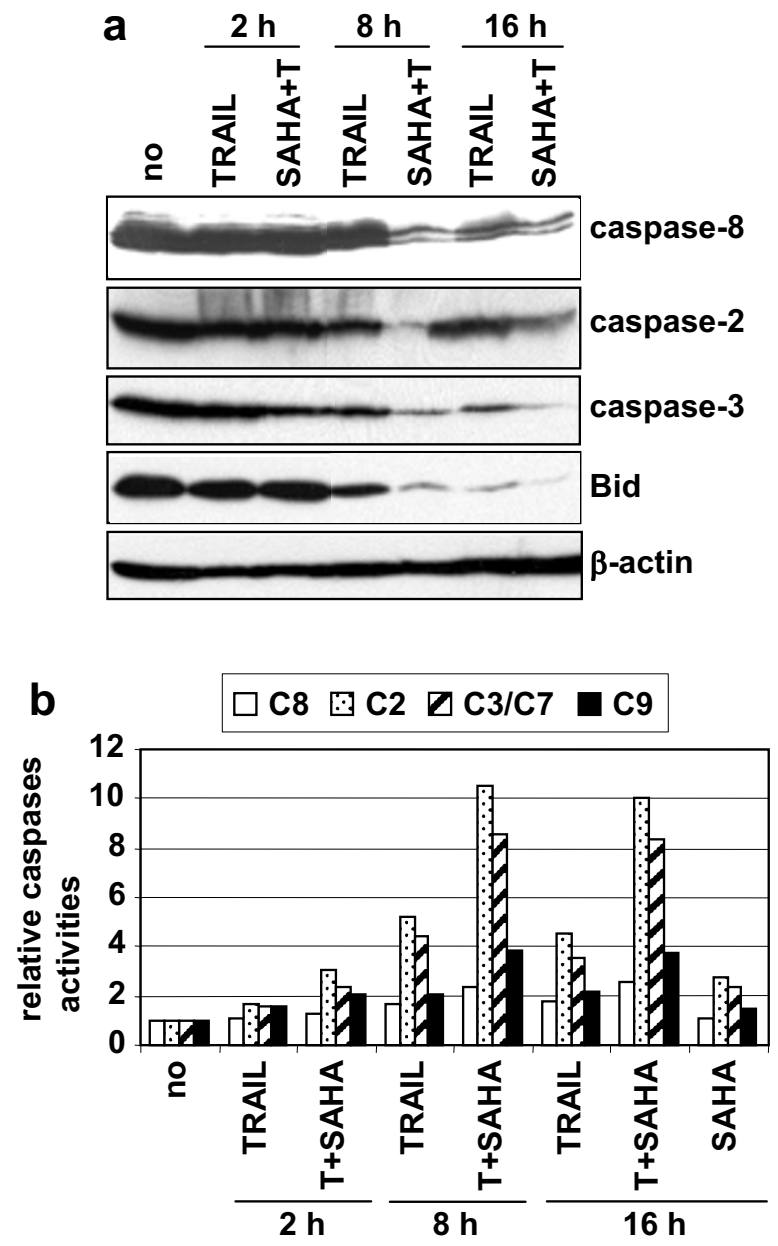

Figure 4

Time-course analysis of caspases activation. A SH-EP cells were unstimulated (no) or stimulated with TRAIL ( 25 $\mathrm{ng} / \mathrm{ml})$ and $\mathrm{M} 2$ ( $125 \mathrm{ng} / \mathrm{ml})(\mathrm{T})$ alone or in combination with SAHA $(2.5 \mu \mathrm{M})$ for 2,8 or $16 \mathrm{~h}$. Whole cell extracts were analysed by immunoblotting for the cleavage of caspases-8, $2,-3$, and Bid. $\beta$-actin was used as loading control. B Timecourse analysis of caspases activation. Caspases-8, -2, -3/7 and -9 activities were measured in lysates of SH-EP cells treated as in a) by measuring the hydrolysis of their respective caspases colorimetric substrates. Caspases activities of stimulated cells, relative to unstimulated cells are indicated.

while other reports have shown no changes in the expression level of DR4, DR5 and DcR2 in melanoma and lymphoma cells [31,37]. No increase in the cell surface expression of TRAIL, TRAIL-R1 and TRAIL-R2 and the decoy receptor TRAIL-R3 was observed in SH-EP and CA2E NB cells after 24 h of treatment with sub-toxic doses of NaB, SAHA or TSA (Fig. 2b and data not shown). These results indicate that the sensitising effect of HDACIs on NB cells acts downstream of the death receptors.

\section{Activation of apoptotic proteins}

To understand the mechanisms of sensitisation to TRAILmediated apoptosis by HDAC inhibitors, the involvement of caspases was analysed using caspases inhibitors. SH-EP cells were strongly protected from apoptosis induced by combined treatment with TRAIL and HDACIs by the caspase-8 (zIETD-fmk), the caspase-3/-7 (zDEVD-fmk), the caspase-9 (zLEHD-fmk), the caspase-2 (zVDVAD-fmk) protease inhibitors and the pan-caspases inhibitor zVADfmk (Fig. 3a). This demonstrates that HDACIs-mediated sensitisation to TRAIL is caspases-dependent.

The extent of caspases activation induced by simultaneous addition of TRAIL and HDACIs was further analysed by immunoblotting in SH-EP cells. Co-incubation with TRAIL and NaB, SAHA or TSA for $16 \mathrm{~h}$ increased the cleavage of procaspases- $8,-2,-3,-7$ and -9 , compared to treatment with TRAIL alone (Fig. 3b). The observed decrease of Bid was also enhanced by combined treatments (Fig. 3b). This resulted in Bid activation by caspases dependent cleavage as further depicted in figure $5 \mathrm{~d}$. In contrast, subtoxic doses of HDACIs alone failed to induce caspases activation or changes in the steady-state level of procaspases-8, -2, -3, -7 and -9, Bid or FADD (Fig. 3b and data not show).

To confirm the increased activation of caspases by combined treatment, the caspase-3-like activity was measured in SH-EP cells. The relative caspase-3-like activities in lysates of cells treated with TRAIL and $\mathrm{NaB}$, SAHA or TSA were superior to that of cells treated with TRAIL alone, whereas no hydrolysis of DEVD-pNA was measured in lysates from cells treated with HDACIs alone (Fig. 3c). These results confirm that the decrease in caspases- 3 and 7 as observed in Fig. 3b, results from caspases activation rather than on deregulation of the pro-caspase expression level.

\section{HDACls increase the magnitude of caspases activation}

The kinetic of caspases cleavage was then analysed by a time-course experiment. Results show that combined treatments with TRAIL and SAHA increased the cleavage of Bid and procaspases- $8,-2$ and -3 , as cleavages became apparent after $8 \mathrm{~h}$ of treatment with TRAIL and SAHA, while only weak cleavages were observed at $8 \mathrm{~h}$ with TRAIL alone (Fig. 4a). Similar results were obtained with TRAIL and $\mathrm{NaB}$, although a faster kinetic of activation was observed (data not shown). Then, the kinetic and the extent of caspases- $8,-3 / 7,-2$ and -9 activation was measured using colorimetric caspases substrates. Interestingly, the maximal level of caspases activation was reached after $8 \mathrm{~h}$ treatment, as no further increase was observed after 16 $\mathrm{h}$ (Fig. 4b). In addition, the extent of caspases activities induced by combined treatments was higher than that induced by TRAIL alone. These analyses suggest that HDA- 
a

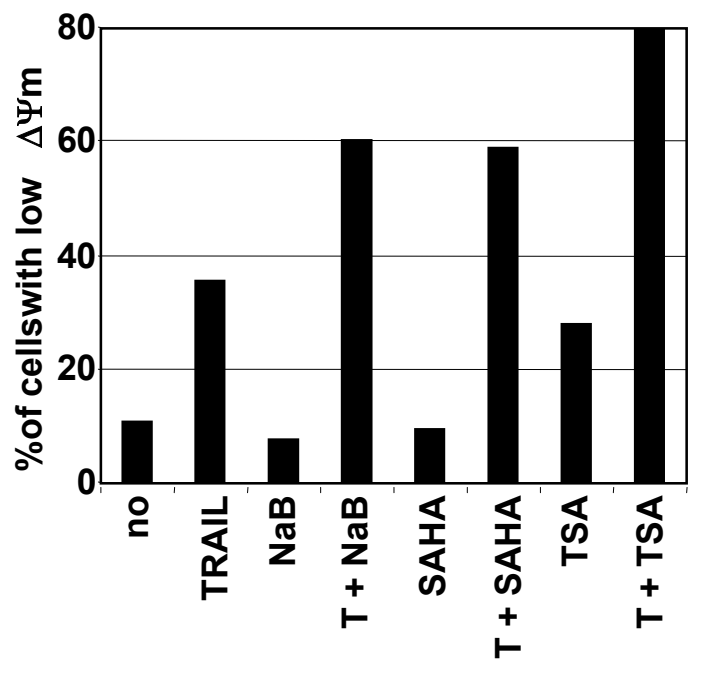

b
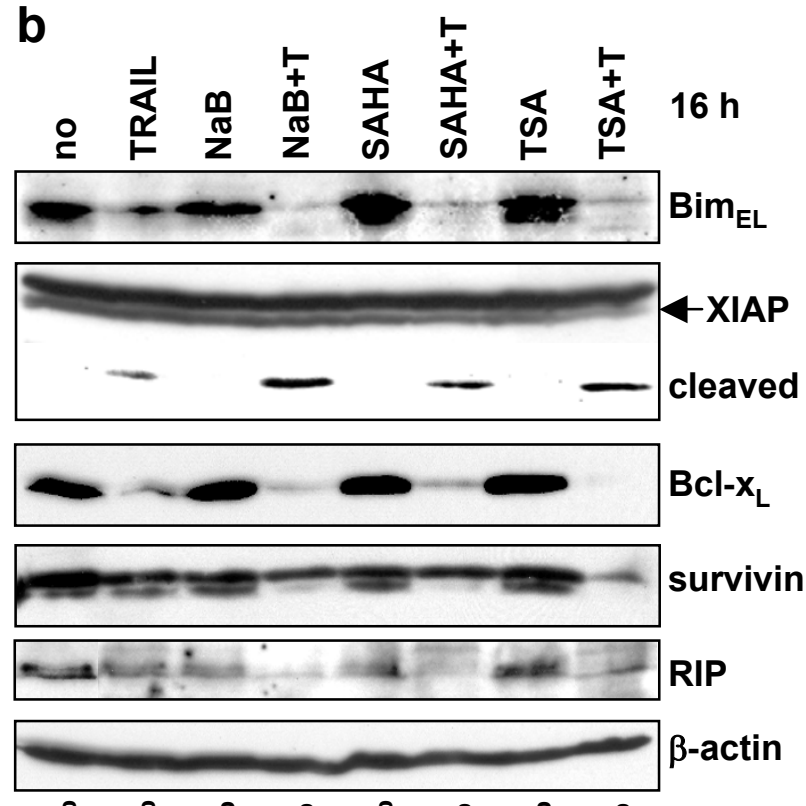

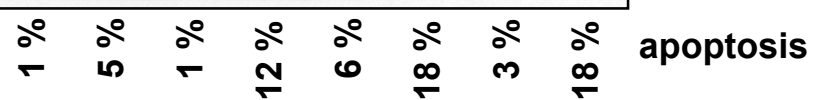

C $\quad 2 \mathrm{~h} 8 \mathrm{~h} 16 \mathrm{~h}$
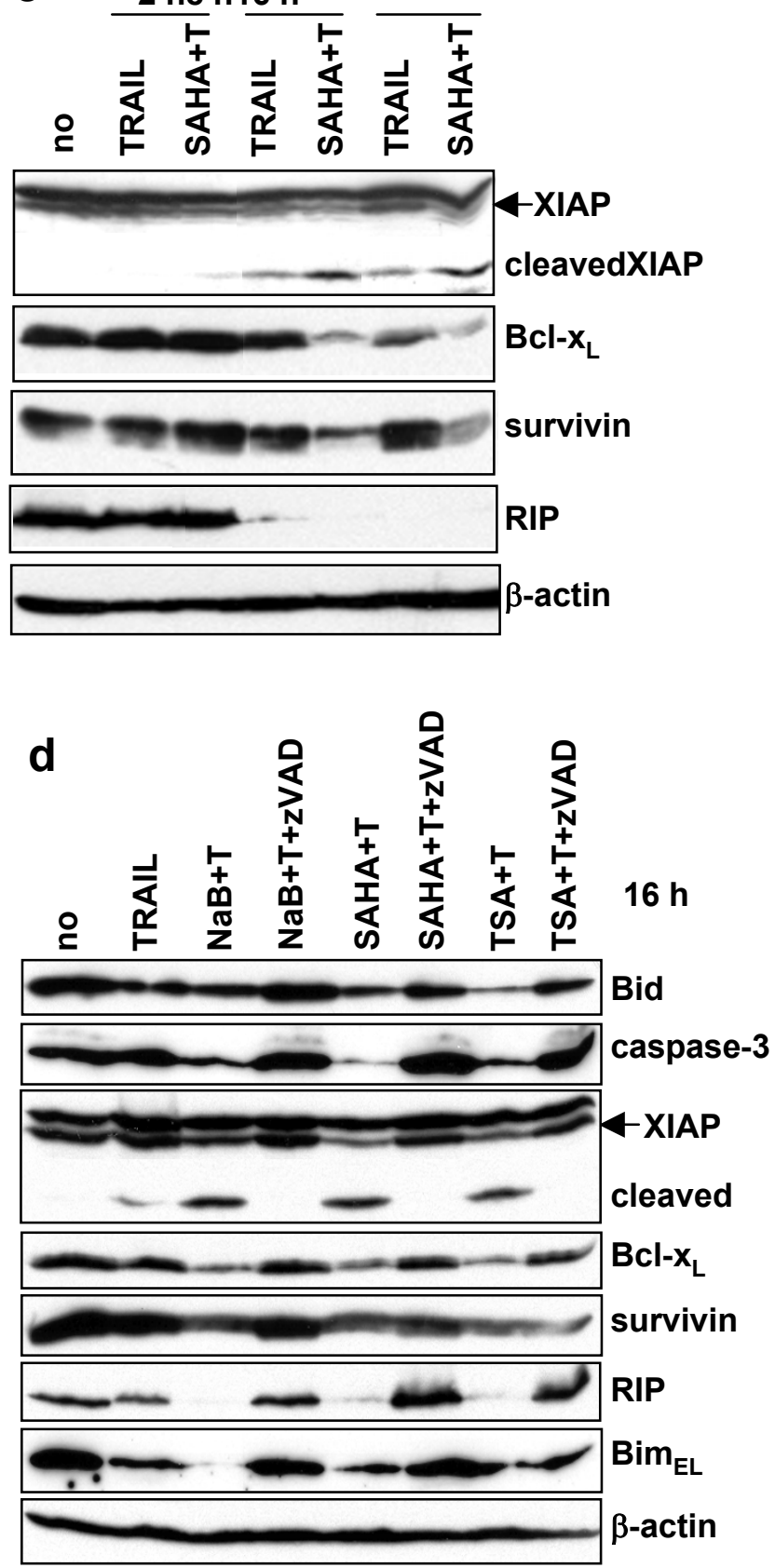

Figure 5

Activation of the mitochondrial signalling pathway. A SH-EP cells were untreated (no) or treated with TRAIL (50 ng/ $\mathrm{ml})$ and $\mathrm{M} 2(250 \mathrm{ng} / \mathrm{ml})(\mathrm{T})$ and/or NaB $(\mathrm{l} \mathrm{mM})$, SAHA $(2.5 \mu \mathrm{M})$ or TSA $(0.5 \mu \mathrm{M})$ for $20 \mathrm{~h}$. The loss of $\Delta \Psi \mathrm{m}$ was measured using the fluorescent probe JC-I. The percentage of cells with low $\Delta \Psi \mathrm{m}$ is indicated. B Simultaneous treatments with TRAIL and HDACls induce inactivation of anti-apoptotic proteins. SH-EP cells were treated as described in Fig. 3b. Percentage of apoptotic cells (sub-GI population) as analysed by the PI staining method after $16 \mathrm{~h}$ of treatments are indicated. $\mathrm{C}$ Timecourse analysis of anti-apoptotic protein cleavage. SH-EP cells were treated as in Fig. 4a. D Co-treatments with TRAIL and HDACls induce caspases-dependent cleavages of pro- and anti-apoptotic proteins. SH-EP cells were untreated or treated with TRAIL $(25 \mathrm{ng} / \mathrm{ml})$ and M2 $(125 \mathrm{ng} / \mathrm{ml})$, or with TRAIL $(\mathrm{T})+\mathrm{NaB}(\mathrm{I} \mathrm{mM}), \mathrm{T}+\mathrm{SAHA}(2.5 \mu \mathrm{M})$ or TSA $(0.5 \mu \mathrm{M})$ in the presence or absence of zVAD for 16 h. b, c, and d. Whole cell extracts were analysed by immunoblotting for the presence of different proand anti-apoptotic proteins. $\beta$-actin was used as loading control. 
CIs sensitise NB cells to TRAIL-induced apoptosis by increasing the extent of caspases activation and thereby enhancing the extent of the apoptotic process.

\section{HDACls increase the activation of the mitochondrial pathway induced by TRAIL}

The observation of an increased cleavage of Bid and caspase-9, as well as the protection by the caspase-9 inhibitor from cell death induced by co-treatment with TRAIL and HDACIs, suggested the involvement of the mitochondrial apoptotic pathway. To analyse this hypothesis, we measured the disruption of the transmembrane mitochondrial potential $(\Delta \Psi \mathrm{m})$ using the fluorescent dye JC-1 in SH-EP cells after TRAIL/HDACIs treatments. TRAIL alone induced a drop of the $\Delta \Psi \mathrm{m}$ in $35 \%$ of the cells after $20 \mathrm{~h}$ of induction, whereas co-treatments with $\mathrm{NaB}$, SAHA or TSA highly increased the number of cells with a reduced $\Delta \Psi \mathrm{m}(60 \%, 59 \%$ and $79 \%$, respectively) (Fig. 5a). No reduction of the $\Delta \Psi \mathrm{m}$ was observed with cells treated with $\mathrm{NaB}$ or SAHA alone, while a weak loss of $\Delta \Psi \mathrm{m}$ was found in cells treated with TSA (Fig.5a). Combined treatments also increased the release of cytochrome $\mathrm{c}$ and AIF from the mitochondria into the cytosol (data not shown). These results indicate that co-treatments with HDACIs increased the activation of the mitochondrial signalling pathway induced by TRAIL.

\section{TRAILIHDACIs co-treatments induce caspases-dependent} inactivation of anti-apoptotic proteins

The stability of several pro- and anti-apoptotic proteins was then analysed in SH-EP cells induced by TRAIL and $\mathrm{NaB}$, SAHA or TSA. A strong decrease in the amount of Bim $_{\mathrm{EL}}$ was observed after $16 \mathrm{~h}$ of combined treatments, whereas TRAIL alone induced only a weak reduction of Bim $_{\mathrm{EL}}$ expression level (Fig. 5b), while Bim $_{\mathrm{L}}$ and Bim $\mathrm{S}_{\mathrm{S}}$ were not detected in SH-EP cells (data not shown). In addition, co-administration of TRAIL and HDACIs increased the down-regulation of the anti-apoptotic proteins XIAP, Bcl$\mathrm{x}_{\mathrm{L}}$, survivin, and RIP, compared to TRAIL alone (Fig. 5b and $5 c$ ). Interestingly, the kinetic of inactivation of antiapoptotic proteins was accelerated by the co-treatment with TRAIL and HDACIs. The cleavage of XIAP and the down-regulation of Bcl- $\mathrm{x}_{\mathrm{L}}$ and survivin observed after $8 \mathrm{~h}$ of treatment with TRAIL and SAHA was stronger than after $16 \mathrm{~h}$ with TRAIL alone (Fig. 5c). Similar results were obtained with TRAIL and $\mathrm{NaB}$ (data not shown). Moreover, the kinetic of inactivation of anti-apoptotic proteins is similar to that of caspases activation by proteolytic cleavages (Fig. 4a).

We have previously shown that the down-regulation of XIAP, Bcl- $\mathrm{x}_{\mathrm{L}}$ and RIP induced by TRAIL and chemotherapeutic drugs was caspases-dependent [19]. To analyse if the reduction of the anti-apoptotic proteins XIAP, $\mathrm{Bcl}-\mathrm{x}_{\mathrm{L}^{\prime}}$ survivin, and RIP induced by co-treatments with TRAIL and HDACIs is likewise caspases-dependent, SH-EP cells were treated with TRAIL and NaB, SAHA or TSA in the presence of the pan-caspases inhibitor zVAD. As shown in figure $5 \mathrm{~d}$, the cleavage of XIAP, and the inactivation of Bcl$\mathrm{x}_{\mathrm{L}}$, survivin, and RIP were protected by the addition of zVAD (Fig. 5d). Similarly, the activation of Bid and caspase- 3 induced by TRAIL and HDACIs were protected by zVAD (Fig. 5d). These results indicate that sensitisation to TRAIL by low doses of HDACIs increases the caspasesdependent cleavages and inactivation of anti-apoptotic proteins. In addition, the amount of Bim $_{\mathrm{EL}}$ was increased in the presence of zVAD indicating that the down-regulation observed by combined treatment was also mediated by caspases-dependent cleavage (Fig. 5d).

\section{Down-regulation of survivin sensitise NB cells to HDACls}

Survivin is over-expressed in most human cancers including NB and was shown to be involved in inhibition of apoptosis in tumour cells [38]. In addition, down-regulation of survivin by siRNAs was shown to sensitise NB cells to TRAIL-induced apoptosis [39]. As survivin steady state level is reduced by co-treatment with TRAIL and HDACIs, we explored its participation in HDACIs-mediated sensitisation to TRAIL. In this aim, survivin expression, was down-regulated in SH-EP cells by RNA interference using survivin siRNAs [36]. As shown in figure 6a, survivin expression level was significantly reduced by survivin siRNA as compared to cells transfected with lipofectamine 2000 or control siRNA. The effect of survivin silencing was analysed by proliferation assay (Fig. 6b). Results show that reduction of survivin expression with $100 \mathrm{nM}$ siRNAs sensitised NB cells to TRAIL alone, to low doses of HDACIs as well as to combined treatments with weak doses of TRAIL and HDACIs (Fig. 6b). Similar results were observed with $25 \mathrm{nM}$ of survivin siRNAs (data not shown). These results indicate that down-regulation of survivin induced by HDACIs and TRAIL may account at least in part to the sensitising effect of HDACIs to TRAILinduced cell death.

\section{Discussion}

The present study demonstrates that simultaneous administration of TRAIL and subtoxic doses of HDACIs strongly potentiates the triggering of apoptotic cascade in NB cells. The detailed analysis of the mechanisms of sensitisation reveals that the increase in cell death is mediated by the enhanced activation of the caspases cascade and the proapoptotic protein Bid, concomitant with the down-regulation of the anti-apoptotic proteins RIP, Bcl- $\mathrm{x}_{\mathrm{L}}, \mathrm{XIAP}$, and survivin in a caspases-dependent manner.

Stimulation of the death receptor pathway through enhancement of death receptor expression is one mechanism of sensitisation to TRAIL by HDACIs. Several recent reports have shown that the expression of TRAIL or TRAIL- 

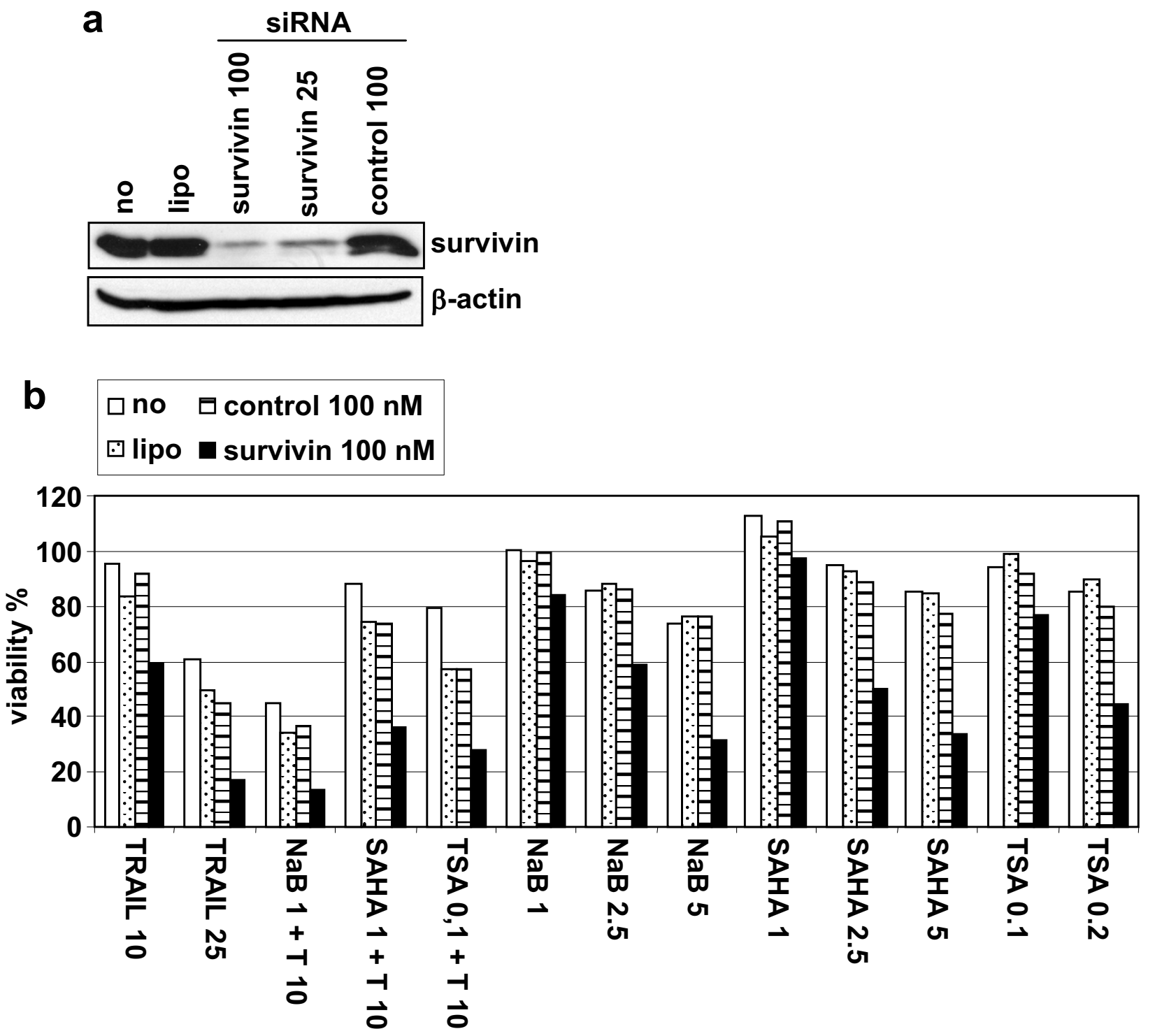

\section{Figure 6}

SiRNAs-mediated down-regulation of survivin expression. A Whole cell extracts of SH-EP cells transfected for $40 \mathrm{~h}$ with lipofectamine 2000 alone (lipo), with survivin siRNA (25 or $100 \mathrm{nM}$ ), control siRNA (I00nM), or untransfected (no) were analysed by immunoblotting for the presence of survivin and $\beta$-actin as loading control.B Survivin down-regulation by siRNAs sensitise NB cells to HDACls. SH-EP cells were untransfected (no), transfected with lipofectamine 2000 (lipo) alone or with survivin siRNA (I00 nM) or control siRNA ( $100 \mathrm{nM})$, and treated $40 \mathrm{~h}$ after transfection with the indicated amounts of $\mathrm{NaB}$ $(\mathrm{mM})$, SAHA, TSA $(\mu \mathrm{M})$ and TRAIL $(\mathrm{ng} / \mathrm{ml})$. Cell death was measured by MTS/PMS cell proliferation assays.

receptors was induced by HDAC inhibitors in leukaemia cells, breast and colon cancer cells [24-28], while other studies have reported no change in the expression level of DR4, DR5 and DcR2 in melanoma and lymphoma cells $[31,37]$. We show here that unlike chemotherapeutic drugs, Doxorubicin, Cisplatin, Etoposide or Taxol which up-regulate the cell surface expression of TRAIL-R2 in NB cells [19], HDACIs did not influence any of TRAIL-R1,
TRAIL-R2 and TRAIL cell surface expression in NB cells, indicating that sensitisation to TRAIL-induced apoptosis by HDACIs occurs at least partly by different mechanisms.

Several studies reported a change in the expression level of proteins involved in the extrinsic apoptotic pathway such as FADD [24] and FLIP $[24,26,29]$. No change in the steady state level of caspases- $8,-2,-3,-7$ and -9 , Bid, FADD 
or FLIP was detected after stimulation with subtoxic doses of NaB, SAHA or TSA in NB cells. Nevertheless, as previously reported in leukaemia cells [31], the death receptor pathway is involved in the synergistic induction of apoptosis by simultaneous treatment with TRAIL and HDACIs in NB cells. Indeed, following over-expression of a FADDDN protein or c-FLIP ${ }_{\mathrm{L}}$ NB cells became fully resistant to TRAIL, which could not be rescued by co-treatments with HDACIs.

In accordance with previous reports $[25,26,32,37,40]$ we demonstrate that HDACIs sensitised NB cells to TRAIL by enhancing the cleavage-mediated activation of the caspases cascade and Bid, while no cleavage was observed with subtoxic doses of HDACIs alone. The enhanced apoptosis induction was caspases-dependent as caspases inhibitors completely abolished NB cell death. Interestingly, TRAIL and HDACIs co-treatments also increased the amplitude of caspases activation. Indeed, a higher level of caspases activities was reached with combined treatment compared to TRAIL alone. This suggests that HDACIs sensitise NB cells to TRAIL-induced apoptosis by enhancing the extent of caspases activation and thereby increasing the magnitude of the apoptotic process.

In addition, the simultaneous addition of TRAIL and HDACIs synergistically affected the mitochondrial pathway as evidenced by the enhanced drop of $\Delta \Psi \mathrm{m}$, the increased caspases- 9 activation and cytochrome $c$ and AIF release into the cytosol. This suggests that HDACIs may also act at the level of the mitochondria to sensitise NB cells to TRAIL, as previously reported with other tumour cell lines [24,31,40].

The modulation of the intracellular ratio between proand anti-apoptotic proteins could be an other mechanism of HDACIs potentiation to TRAIL-induced apoptosis, which could occur by the increased activity of pro-apoptotic proteins and/or by the down-regulation of antiapoptotic proteins. The $\mathrm{BH} 3$-only protein $\mathrm{Bim}_{\mathrm{EL}}$ was reported to be increased by subtoxic doses of TSA and depsipeptide in CCL and Jurkat cells [32]. Here we show

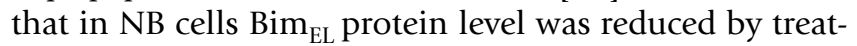
ment with TRAIL and further decreased by co-administration of HDACIs. This was due to caspases-dependent cleavage as the down-regulation of $\mathrm{Bim}_{\mathrm{EL}}$ was protected by zVAD. Interestingly, the activation of Bim $_{\mathrm{EL}}$ by caspases-3dependent cleavage was described to induce a positive feedback amplification of the apoptotic signal by enhancing the affinity of $\mathrm{Bim}_{\mathrm{EL}}$ to Bcl-2 [41]. Therefore, in NB cells Bim $_{\mathrm{EL}}$ may be activated by caspases-mediated cleavage following combined treatment and such Bim $\mathrm{EL}_{\mathrm{E}}$ activation may participate to TRAIL potentiation by HDACIs through the amplification of the apoptotic signal. In addition, we observed the reduction of the anti-apoptotic pro- tein $\mathrm{Bcl}-\mathrm{x}_{\mathrm{L}}$ following combined treatments. Hence, the increase of the $\mathrm{Bim}_{\mathrm{EL}} / \mathrm{Bcl}-\mathrm{x}_{\mathrm{L}}$ ratio could enhance mitochondrial permeability leading to the release of pro-apoptotic factors.

The caspases-dependent down-regulation of anti-apoptotic proteins such as XIAP and Bcl-2 [31] and the role of the down-regulation of $\mathrm{Bcl}-\mathrm{x}_{\mathrm{L}}$ [30] by co-treatment with TRAIL and HDACIs were previously described. In an other report it was shown that the reduction of $\mathrm{c}-\mathrm{FLIP}, \mathrm{Bcl}-\mathrm{x}_{\mathrm{L}^{\prime}}$ Bcl-2, and XIAP expression induced by subtoxic doses of the HDACI LAQ824 was independent on proteasome or caspases activity [26]. In contrast, we demonstrate here that the steady state level of RIP, Bcl- $\mathrm{x}_{\mathrm{L}}$, XIAP and survivin in NB cells was reduced by caspases-dependent cleavages mediated by co-treatments with TRAIL and HDACIs. Interestingly, both the level and the timing of down-regulation of anti-apoptotic proteins were increased by combined treatments compared to TRAIL alone. The concomitant caspases-dependent down-regulation of the anti-apoptotic proteins RIP, Bcl- $\mathrm{x}_{\mathrm{L}}$, XIAP, and survivin, and the activation of the pro-apoptotic proteins Bid and probably Bim $\mathrm{EL}_{\mathrm{inc}}$ ineased the ratio between pro- and antiapoptotic proteins and therefore lowered the threshold of apoptotic signal and contributed to the sensitising effect of HDACIs to TRAIL-induced apoptosis.

We have previously shown that RIP, $\mathrm{Bcl}-\mathrm{x}_{\mathrm{L}}$, and XIAP were down-regulated by caspases-dependent cleavages upon co-treatment with TRAIL and chemotherapeutic drugs, while the steady state level of survivin was not affected, in contrast to co-treatment with TRAIL and HDACIs [19]. This indicates that HDACIs and chemotherapeutic drugs contribute through different ways to TRAIL-induced apoptosis. The reduction of survivin expression mediated by siRNAs results in an increased the sensitivity threshold of NB cells to HDACIs and/or TRAIL. This suggests that the down-regulation of survivin induced by higher doses of HDACIs and TRAIL plays a role in the sensitising effect of HDACIs to TRAIL.

\section{Conclusion}

The potentiation by HDACIs to TRAIL-induced apoptosis may be caused by stimulation of the apoptotic cascade through increased activation of both the extrinsic and the intrinsic apoptotic pathways induced by TRAIL and HDACIs, respectively. The apoptotic signal is further enhanced by the caspases-dependent activation of pro-apoptotic proteins such as Bid and $\mathrm{Bim}_{\mathrm{el}}$ and inactivation of antiapoptotic proteins such as XIAP, Bcl- $\mathrm{X}_{\mathrm{L}}, \mathrm{RIP}$, and survivin. It results a change in the equilibrium of pro- to anti-apoptotic molecules that lowers the cell death threshold and strongly favours apoptosis. 
These findings may have important implications for the use of TRAIL in cancer therapeutic using recombinant soluble TRAIL. As HDACIs strongly enhance the apoptotic action of TRAIL even at low concentrations, HDACIs may be used in combination with TRAIL to reduce the doses of TRAIL required for inhibition of tumour growth. Recently, several HDAC inhibitors have entered Phase I and Phase II clinical trials and are demonstrating encouraging antitumour activity in a variety of cancer types (21). The combination of TRAIL and HDACIs may therefore be an interesting and soft inoffensive new anti-tumour strategy particularly relevant in the treatment of children with highly malignant neuroblastoma.

\section{Abbreviations}

TRAIL: Tumour Necrosis Factor-related apoptosis-inducing ligand, NB: Neuroblastoma, HDACIs: histone deacetylase inhibitors, NaB: sodium butyrate, SAHA: suberoylanilide hydroxamic acid, TSA: Trichostatin A, CHX: cycloheximide, DOX: doxorubicin, DISC: Death Inducing Signalling Complex, c-FLIP: cellular Flice inhibitory protein, IAP: inhibitor of apoptosis protein.

\section{Competing interests}

The author(s) declare that they have no competing interests.

\section{Authors' contributions}

AMM performed all major experimental work including FACS analyses, participated in the design and in the coordination of the study and drafted the manuscript. KBB participated in all cell culture experiments and performed the immunoblots, caspases activity assays. KA participated in the immunoblotting experiment and in cells stimulation with drugs. MF helped for the siRNA transfections. RM participated in cell treatments with HDACIs. JMJ and NG were involved in the overall design of the study and helped to draft the manuscript.

\section{Acknowledgements}

We thank J. Tschopp for providing us with TRAIL and U. ZangemeisterWittke for the gift of survivin and control siRNAs.

This work was supported by grants from the Swiss Cancer League (to NG, KFS 1086-09-2000), from the Swiss National Scientific Foundation (to NG, 3100-0679|8.02) and from FORCE Foundation.

\section{References}

I. Maris JM, Matthay KK: Molecular biology of neuroblastoma. J Clin Oncol 1999, 17:2264-2279.

2. Brodeur GM: Neuroblastoma: biological insights into a clinical enigma. Nat Rev Cancer 2003, 3:203-216.

3. Hengartner MO: The biochemistry of apoptosis. Nature 2000, 407:770-776.

4. Ashkenazi A, Dixit VM: Death receptors: signaling and modulation. Science 1998, 281:1305-1308.

5. Ashkenazi A: Targeting death and decoy receptors of the tumour-necrosis factor superfamily. Nat Rev Cancer 2002, 2:420-430.
6. Slee EA, Harte MT, Kluck RM, Wolf BB, Casiano CA, Newmeyer DD, Wang HG, Reed JC, Nicholson DW, Alnemri ES, Green DR, Martin SJ: Ordering the cytochrome c-initiated caspase cascade: hierarchical activation of caspases-2, $-3,-6,-7,-8$, and -10 in a caspase-9- dependent manner. J Cell Biol 1999, I 44:28I-292.

7. Von Haefen C, Wieder T, Essmann F, Schulze-Osthoff K, Dorken B, Daniel PT: Paclitaxel-induced apoptosis in BJAB cells proceeds via a death receptor-independent, caspases-3/-8driven mitochondrial amplification loop. Oncogene 2003, 22:2236-2247.

8. Yin XM, Wang K, Gross A, Zhao Y, Zinkel S, Klocke B, Roth KA, Korsmeyer SJ: Bid-deficient mice are resistant to Fas-induced hepatocellular apoptosis. Nature 1999, 400:886-891.

9. Irmler M, Thome M, Hahne M, Schneider P, Hofmann K, Steiner V, Bodmer JL, Schroter M, Burns K, Mattmann C, Rimoldi D, French LE, Tschopp J: Inhibition of death receptor signals by cellular FLIP [see comments]. Nature 1997, 388:190-195.

10. Kuwana T, Newmeyer DD: Bcl-2-family proteins and the role of mitochondria in apoptosis. Curr Opin Cell Biol 2003, 15:691-699.

II. Salvesen GS, Duckett CS: IAP proteins: blocking the road to death's door. Nat Rev Mol Cell Biol 2002, 3:40I-4IO.

12. Igney FH, Krammer PH: Death and anti-death: tumour resistance to apoptosis. Nat Rev Cancer 2002, 2:277-288.

13. Eggert A, Grotzer MA, Zuzak TJ, Wiewrodt BR, Ho R, Ikegaki N, Brodeur GM: Resistance to tumor necrosis factor-related apoptosis-inducing ligand (TRAIL)-induced apoptosis in neuroblastoma cells correlates with a loss of caspase-8 expression. Cancer Res 2001, 61:1314-1319.

14. Hopkins-Donaldson S, Bodmer JL, Bourloud KB, Brognara CB, Tschopp J, Gross N: Loss of caspase-8 expression in highly malignant human neuroblastoma cells correlates with resistance to tumor necrosis factor-related apoptosis-inducing ligand-induced apoptosis. Cancer Res 2000, 60:4315-4319.

15. Teitz T, Wei T, Valentine MB, Vanin EF, Grenet J, Valentine VA, Behm FG, Look AT, Lahti JM, Kidd VJ: Caspase 8 is deleted or silenced preferentially in childhood neuroblastomas with amplification of MYCN. Nat Med 2000, 6:529-535.

16. Yang X, Merchant MS, Romero ME, Tsokos M, Wexler LH, Kontny $U$, Mackall CL, Thiele C): Induction of caspase 8 by interferon gamma renders some neuroblastoma (NB) cells sensitive to tumor necrosis factor-related apoptosis-inducing ligand (TRAIL) but reveals that a lack of membrane TRI/TR2 also contributes to TRAIL resistance in NB. Cancer Res 2003 , 63:1122-1129.

17. Wajant H, Pfizenmaier K, Scheurich P: TNF-related apoptosis inducing ligand (TRAIL) and its receptors in tumor surveillance and cancer therapy. Apoptosis 2002, 7:449-459.

18. Ozoren N, El Deiry WS: Cell surface death receptor signaling in normal and cancer cells. Seminars in Cancer Biology 2003, 13:135-147.

19. Muhlethaler-Mottet A, Bourloud KB, Auderset K, Joseph JM, Gross $\mathrm{N}$ : Drug-mediated sensitization to TRAIL-induced apoptosis in caspase-8-complemented neuroblastoma cells proceeds via activation of intrinsic and extrinsic pathways and caspasedependent cleavage of XIAP, Bcl-x(L) and RIP. Oncogene 2004, 23:5415-5425.

20. Secrist JP, Zhou X, Richon VM: HDAC inhibitors for the treatment of cancer. Curr Opin Investig Drugs 2003, 4: 1422-1427.

21. Johnstone RW: Histone-deacetylase inhibitors: novel drugs for the treatment of cancer. Nat Rev Drug Discov 2002, I:287-299.

22. Marks P, Rifkind RA, Richon VM, Breslow R, Miller T, Kelly WK: Histone deacetylases and cancer: causes and therapies. Nat Rev Cancer 200I, I: 194-202.

23. Jones PA, Baylin SB: The fundamental role of epigenetic events in cancer. Nat Rev Genet 2002, 3:415-428.

24. Chopin V, Slomianny C, Hondermarck H, Le Bourhis X: Synergistic induction of apoptosis in breast cancer cells by cotreatment with butyrate and TNF-alpha, TRAIL, or anti-Fas agonist antibody involves enhancement of death receptors' signaling and requires P2I(wafl). Experimental Cell Research 2004, 298:560-573.

25. Nakata S, Yoshida T, Horinaka M, Shiraishi T, Wakada M, Sakai T: Histone deacetylase inhibitors upregulate death receptor 5 / TRAIL-R2 and sensitize apoptosis induced by TRAIL/APO2$L$ in human malignant tumor cells. Oncogene 2004, 23:626|-627I. 
26. Guo F, Sigua C, Tao J, Bali P, George P, Li Y, Wittmann S, Moscinski L, Atadja P, Bhalla K: Cotreatment with histone deacetylase inhibitor LAQ824 enhances Apo-2L/tumor necrosis factorrelated apoptosis inducing ligand-induced death inducing signaling complex activity and apoptosis of human acute leukemia cells. Cancer Res 2004, 64:2580-2589.

27. Nebbioso A, Clarke N, Voltz E, Germain E, Ambrosino C, Bontempo P, Alvarez R, Schiavone EM, Ferrara F, Bresciani F, Weisz A, de Lera AR, Gronemeyer $\mathrm{H}$, Altucci L: Tumor-selective action of HDAC inhibitors involves TRAIL induction in acute myeloid leukemia cells. Nat Med 2005, I I:77-84.

28. Insinga A, Monestiroli S, Ronzoni S, Gelmetti V, Marchesi F, Viale A, Altucci L, Nervi C, Minucci S, Pelicci PG: Inhibitors of histone deacetylases induce tumor-selective apoptosis through activation of the death receptor pathway. Nat Med 2005, I I:7 I-76.

29. Watanabe K, Okamoto K, Yonehara S: Sensitization of osteosarcoma cells to death receptor-mediated apoptosis by HDAC inhibitors through downregulation of cellular FLIP. Cell Death Differ 2005, I 2:10-18.

30. Neuzil J, Swettenham E, Gellert N: Sensitization of mesothelioma to TRAIL apoptosis by inhibition of histone deacetylase: role of $\mathbf{B c l}-\mathbf{x L}$ down-regulation. Biochem Biophys Res Commun 2004, 3 | 4: | 86-| 91 .

31. Rosato RR, Almenara JA, Dai Y, Grant S: Simultaneous activation of the intrinsic and extrinsic pathways by histone deacetylase (HDAC) inhibitors and tumor necrosis factor-related apoptosis-inducing ligand (TRAIL) synergistically induces mitochondrial damage and apoptosis in human leukemia cells. Mol Cancer Ther 2003, 2:1273-1284

32. Inoue S, MacFarlane M, Harper N, Wheat LM, Dyer MJ, Cohen GM: Histone deacetylase inhibitors potentiate TNF-related apoptosis-inducing ligand (TRAIL)-induced apoptosis in lymphoid malignancies. Cell Death Differ 2004, I I Suppl 2:S I 93-S206.

33. Hopkins-Donaldson S, Yan P, Bourloud KB, Muhlethaler A, Bodmer JL, Gross N: Doxorubicin-induced death in neuroblastoma does not involve death receptors in S-type cells and is caspase-independent in $\mathbf{N}$-type cells. Oncogene 2002, 2 I:6132-6137.

34. Flahaut M, Muhlethaler-Mottet A, Auderset K, Balmas BK, Meier R, Joseph JM, Beck Popovic M, Gross N: Persistent inhibition of FLIPL expression by lentiviral small hairpin RNA delivery restores death-receptor-induced apoptosis in neuroblastoma cells. Apoptosis 2005.

35. Sokol RJ, Straka MS, Dahl R, Devereaux MW, Yerushalmi B, Gumpricht $\mathrm{E}$, Elkins N, Everson G: Role of oxidant stress in the permeability transition induced in rat hepatic mitochondria by hydrophobic bile acids. Pediatr Res 200I, 49:519-531.

36. Belyanskaya LL, Hopkins-Donaldson S, Kurtz S, Simoes-Wust AP, Yousefi S, Simon HU, Stahel R, Zangemeister-Wittke U: Cisplatin activates Akt in small cell lung cancer cells and attenuates apoptosis by survivin upregulation. Int I Cancer 2005, I 1 7:755-763.

37. Zhang XD, Gillespie SK, Borrow JM, Hersey P: The histone deacetylase inhibitor suberic bishydroxamate: a potential sensitizer of melanoma to TNF-related apoptosis-inducing ligand (TRAIL) induced apoptosis. Biochem Pharmacol 2003 66:1537-1545

38. Altieri DC: Validating survivin as a cancer therapeutic target. Nat Rev Cancer 2003, 3:46-54.

39. Fulda S, Debatin KM: Sensitization for tumor necrosis factorrelated apoptosis-inducing ligand-induced apoptosis by the chemopreventive agent resveratrol. Cancer Res 2004 64:337-346.

40. Sonnemann J, Gange J, Kumar KS, Muller C, Bader P, Beck JF: Histone deacetylase inhibitors interact synergistically with tumor necrosis factor-related apoptosis-inducing ligand (TRAIL) to induce apoptosis in carcinoma cell lines. Invest New Drugs 2005, 23:99-109.

4I. Chen D, Zhou Q: Caspase cleavage of BimEL triggers a positive feedback amplification of apoptotic signaling. Proc Natl Acad Sci U S A 2004, I 0 I : | 235- I 240.

\section{Pre-publication history}

The pre-publication history for this paper can be accessed here: http://www.biomedcentral.com/1471-2407/6/214/pre pub
Publish with Biomed Central and every scientist can read your work free of charge

"BioMed Central will be the most significant development for disseminating the results of biomedical research in our lifetime. "

Sir Paul Nurse, Cancer Research UK

Your research papers will be:

- available free of charge to the entire biomedical community

- peer reviewed and published immediately upon acceptance

- cited in PubMed and archived on PubMed Central

- yours - you keep the copyright

Submit your manuscript here:

http://www.biomedcentral.com/info/publishing_adv.asp
BioMedcentral 